\title{
ADAT KAWIN LARI “MERARIQ” DALAM MASYARAKAT SUKU SASAK DI DESA LENDANG NANGKA
}

\author{
Dian Eka Mayasari S.W \\ Program Studi Pendidikan Sejarah, Universitas Muhammadiyah Mataram, dianekamaya30s@gmail.com
}

\begin{tabular}{l} 
INFO ARTIKEL \\
RiwayatArtikel: \\
Diterima: 02-11-2016 \\
Disetujui: 02-12-2016 \\
\hline
\end{tabular}

Kata Kunci:

1.Adat Merariq

2. Suku Sasak

\begin{abstract}
ABSTRAK
Abstrak:

Tujuan penelitian mengkaji nilai-nilai dalam prosesi adat " merariq", menganalisis pergeseran nilai adat "merariq" seiring dinamika perubahan sosial masyarakatnya serta menganalisis implikasi adat "merariq" terhadap kehidupan keluarga, sosial dan hukum formal. Metode yang digunakan kualitatif bersifat deskriptif. Teknik pengumpulan data yang digunakan observasi, wawancara, dan dokumentasi. Analisis data menggunakan reduksi data, penyajian data, dan penarikan kesimpulan. Validitas data menggunakan teknik triangulasi. Hasil penelitian menunjukkan bahwa serangkaian prosesi merariq mengandung nilai-nilai budaya, nilai-nilai pendidikan, nilai agama, nilai ekonomi dan nilai seni. Pergeseran nilai adat "merariq" meliputi proses midang dan proses merariq yang saat ini tidak dilakukan secara lengkap. Implikasi adat "merariq" menurut KUH Pidana merariq atau membawa lari perempuan merupakan suatu tindak pidana karena telah mengambil anak gadis dari kekuasaan orang tuanya. Tetapi pada kenyataannya merariq tidak bisa ditindak pidana karena adanya pertentangan dari hukum adat dalam masyarakat setempat.

The objectives of the study examined the process of customary process "merariq", analyzing customary change "merariq" the emergence of the dynamics of social change of society and the customary implications of "merariq" on family, social and legal life. The method used is qualitative descriptive. Data completion technique used observation, interview, and documentation. Data analysis uses data reduction, presentation data, and withdrawals. Data validity using triangulation technique. The results showed that there were uniform processions. The customary shift of "merariq" process process of field and process merariq which is not currently done completely. The customary implication of "merariq" according to the Criminal Code merariq or take away is a crime because it has taken the girl from the power of his parents. Not in answer merariq can not be criminalized because of the contradiction of customary law in local communities.
\end{abstract}

\section{A. LATAR BELAKANG}

Adat merupakan pencerminan kepribadian suatu bangsa, merupakan salah satu penjelmaan dari pada jiwa bangsa (volkgeist) yang bersangkutan dari abad ke abad. Setiap bangsa di dunia ini memiliki adat kebiasaan sendiri yang satu dengan yang lainnya tidak sama. Justru karena sifat ketidaksamaan itulah kita dapat menyatakan bahwa adat itu merupakan unsur yang penting yang memberikan identitas bangsa yang bersangkutan (Lukman, 2008: 6).

Di Indonesia adat yang dimiliki oleh daerahdaerah, suku bangsa adalah berbeda-beda meskipun dasar sifatnya adalah satu, yaitu ke Indonesiaannya. Berdasarkan hal itu, maka adat bangsa Indonesia merupakan "Bhinneka Tunggal Ika". Adat Bhinneka Tunggal Ika tidak akan mati melainkan selalu berkembang, selalu dalam keadaan evolusi mengikuti proses perkembangan peradaban bangsanya. Adat istiadat hidup serta berhubungan dengan tradisi rakyat merupakan sumber yang menggunakan hukum adat di Indonesia (Rato, 2011: 2).Kebudayaan daerah yang beranekagaram itu merupakan khasanah budaya tidak ternilai harganya dan perlu mendapat perhatian dari pemerintah dan pihakpihak lain yang terkait. Salah satu adat dan kebiasaan dewasa ini menjadi fokus perhatian masing-masing daerah adalah adat istiadat perkawinan Seluruh makhluk hidup di dunia ini diciptakan oleh Tuhan berpasang-pasangan, ada laki-laki dan perempuan. Termasuk salah satunya adalah kita, manusia sebagai makhluk yang paling sempurna dan tidak dapat hidup sendiri. Untuk memenuhi kebutuhannya, manusia membutuhkan mitra dalam hidupnya dan untuk 
memperoleh mitra tersebut manusia kemudian mencari pasangan hidup melalui jalan pernikahan. Hal ini juga disebut dalam Al'Quran surat Ar-Rum ayat 21 yang artinya: "Dan diantara tanda-tanda kekuasaan-Nya adalah menciptakan untuk kalian istri-istri dari jenis kalian sendiri, supaya kalian cenderung dan merasa tentram kepadanya, juga menjadikannya diantara kalian rasa kasih sayang. Sesungguhnya pada yang demikian itu benarbenar terdapat tanda-tanda bagi kaum yang berfikir" (Mas'ud dalam Yasin 2008:141).

Masyarakat Suku Sasak yang mendiami pulau Lombok memiliki beberapa sistem perkawinan diantaranya; merariq, meminang atau melamar, kawin tadong atau kawin gantung, memagah dan mesapok. Namun yang menjadi fokus dalam penelitian ini adalah adat kawin lari "merariq" merupakan bentuk perkawinan yang biasa terjadi karena sudah merupakan suatu kebiasaan yang ditetapkan dan diatur di dalam hukum adat Suku Sasak. Menurut sejarah munculnya tradisi kawin lari "merariq" di pulau Lombok, Bartholomew (2001:203) mengungkapkan bahwa praktik kawin lari dipinjam dari budaya Bali. Analisis antropologis historis yang dilakukan Clifford Geertz dalam bukunya Internal Convention in Bali (1973), Hildred Geertz dalam tulisannya An Anthropology of Religion andMagic (1975), dan James Boon dalam bukunya The Anthropological Romance of Bali (1977), seperti dikutip Bartolomew, memperkuat pendapat akulturasi budaya Bali dan Lombok dalam merariq. Salam (1992:22) menegaskan bahwa praktik kawin lari di Lombok merupakan pengaruh dari tradisi kasta dalam budaya Hindhu Bali. Berdasarkan kedua argumen tentang sejarah kawin lari (merariq) tersebut peneliti menyimpulkan bahwa kawin lari "merariq" dipengaruhi oleh culture Bali, memperoleh konstribusi sosial politik dari warisan Hindu Bali serta menjadi sebuah tradisi yang dipertahankan sampai saat ini oleh masyarakatnya.

Adat perkawinan pada masyarakat Suku Sasak dilakukan dengan cara merariq (kawin lari) yaitu merupakan bentuk perkawinan yang paling ngetren dan disukai yakni lari bersama antara pemuda dan gadis saling mencintai, dalam bahasa sasak dikenal dengan pede mele. Perundingan-perundingan antara si pemuda dan gadis diselenggarakan melalui lembaga adat yang disebut midang atau ngayo.

Keberadaan atau eksistensi kawin lari (merariq) pada masyarakat Suku Sasak tetap dipertahankan, disebabkan: adanya rasa hina dari orang tua si gadis kalau anaknya dilamar, dan adanya pandangan masyarakat setempat bahwa anak gadis bukanlah merupakan barang yang diperjual-belikan. Mereka lebih senang bila anaknya dilarikan karena sejalan dengan adat istiadat. Di samping itu juga kawin lari "merariq" tidak akan membuat perjaka atau bajang kecewa walaupun ternyata mereka kepaten (ditinggalkan kekasihnya) (Daliem, 2002: 12).

Pada zaman dahulu kawin lari pada masyarakat Suku Sasak betul-betul dianggap tabu artinya orang tua si gadis betul-betul tidak tahu menahu tentang perkawinan anaknya karena bila diberitahu mereka beranggapan si gadis tidak punya etika dan perilaku yang sopan, sehingga sebagian besar si gadis dan si pemuda menempuh kawin lari (merariq) tanpa pemberitahuan rencana perkawinannya.

Berbeda dengan perkembangan merariq (kawin lari) dewasa ini yaitu paling tidak orang tua mengetahui rencana orang tuanya namun mereka tidak mencampuri rencana-rencana anaknya yang pede mele (sama-sama mau). Sehingga ada pergeseran terhadap nilai-nilai atau kawin lari lama terhadap perkawinan lari sekarang ini. Orang tua terutama ibu demikian pekanya terhadap tindakan dan gerak-gerik anaknya, lebih-lebih apabila seseorang pemuda seringkali datang bertandang (midang) menjumpai anaknya sehingga hal ini menimbulkan pergeseran nilai-nilai. Agar mereka sedang midang tidak melanggar adat sopan santun di dalam kampung atau desa dan adat keluarga pihak gadis, maka disediakan tempat untuk si pemuda dan gadis yang midang adalah berugaq, sebuah bale-bale untuk menerima tamu terletak di depan rumah dalam keadaan terbuka sehingga terlihat jauh (Daliem, 2002: 14).

Dari gambaran singkat tersebut di atas dapat dikatakan bahwa sebagian besar masyarakat Suku Sasak melakukan suatu perkawinan dengan cara merariq atau kawin lari dan itu merupakan suatu warisan historis sejak nenek moyang yang perlu terus dipupuk dan dilestarikan. 
Sisi lain adat kawin lari "merariq" juga ditentang terutama pada masyarakat-masyarakat feodal atau yang masih fanatik dengan kebangsawanannya yang berdampak terhadap perlawanan adat yang berlaku.

Zuhdi (2004) menunjukkan bahwa merariq bagi masyarakat Sasakberarti mempertahankan harga diri dan menggambarkan sikap kejantanan seorang pria Sasak, karena ia berhasil mengambil (melarikan) seorang gadis pujaan hatinya. Sedangkan Yasin (2006) mengemukakan empat prinsip dasar dalam praktek kawin lari (merariq) yaitu Pertama, prestise keluarga perempuan. Kedua, Superioritas, lelaki, inferioritas perempuan. Ketiga, egalitarianisme dan Keempat, komersial.

Merariq sebagai sebuah tradisi yang biasa berlaku pada suku Sasak di Lombok ini memiliki logika tersendiri yang unik. Bagi masyarakat Sasak, merariq berarti mempertahankan harga diri dan menggambarkan sikap kejantanan seorang pria Sasak, karena ia berhasil mengambil (melarikan) seorang gadis pujaan hatinya. Sementara pada sisi lain, bagi orang tua gadis yang dilarikan juga cenderung enggan, kalau tidak dikatakan gengsi, untuk memberikan anaknya begitu saja jika diminta secara biasa (konvensional), karena mereka beranggapan bahwa anak gadisnya adalah sesuatu yang berharga, jika diminta secara biasa, maka dianggap seperti meminta barang yang tidak berharga. Ada ungkapan yang biasa diucapkan dalam bahasa Sasak: Ara'm ngendeng anak manok baen (seperti meminta anak ayam saja). Jadi dalam konteks ini, merariq dipahami sebagai sebuah cara untuk melakukan prosesi pernikahan, di samping cara untuk keluar dari konflik.

Berdasarkan uraian di atas, maka peneliti tertarik untuk mengkaji lebih dalam tentang pergeseran nilai-nilai dan implikasi adat kawin lari "merariq". Oleh karena itu peneliti memfokuskan pada kajian; a) Nilai-nilai yang terkandung dalam prosesi adat kawin lari "merariq"; b) Bagaimana pergeseran nilai pada adat kawin lari "merariq" dalam masyarakat Suku Sasak seiring dengan adanya dinamika perubahan sosial yang menerpa masyarakat Suku Sasak; c) Bagaimana implikasi adat kawin lari "merariq" terhadap kehidupan keluarga, sosial, agama dan hukum formal yang berlaku saat ini.

\section{B. METODE PENELITIAN}

Penelitian ini menggunakan metode kualitatif, sebagaimana yang dinyatakan Moleong (2007:5) bahwa pendekatan kualitatif yaitu penelitian yang bermaksud untuk memahami fenomena tentang apa yang dialami oleh subjek penelitian, misalnya perilaku, persepsi, motivasi, tindakan dan lain-lain secara holistik dan dengan cara deskriptif dalam bentuk kata-kata dan bahasa, pada suatu konteks khusus yang alamiah dan dengan memanfaatkan berbagai metode alamiah. Pendekatan ini dipilih, sebab peneliti ingin mengkaji perilaku masyarakat Suku Sasak. Dalam penelitian ini difokuskan pada adat kawin lari "merariq" dalam masyarakat Suku Sasak Lombok. Penelitian jenis kualitatif tidak hanya menetapkan penelitian berdasarkan variabel peneliti, tetapi keseluruhan situasi sosial yang diteliti yang meliputi aspek tempat (place), pelaku (actor) dan aktivitas (activity) yang berinteraksi secara sinergis (Sugiyono, 2008:207).

Lokasi penelitian yang dipilih oleh peneliti adalah Desa Lendang Nangka. Data yang dikumpulkan berupa data primer yakni data yang diperoleh secara langsung dari masyarakat Suku Sasak diantaranya tokoh masyarakat (seperti perangkat desa dan dinas pariwisata Lombok Timur), keenam pasang pelaku adat merariq, orang tua kedua mempelai, masyarakat, tokoh adat, tokoh agama dan aparat penegak hukum dan data sekunder yang diperoleh dari dokumentasi; berupa arsip-arsip, bukubuku, surat kabar, majalah, agenda dan lain-lain sebagai bukti yang menunjukkan peristiwa atau kegiatan yang berhubungan dengan penelitian ini. Metode pengumpulan data dalam penelitian ini menggunakan metode observasi, wawancara dan dokumentasi.

Validitas data dilakukan dengan menggunakan teknik triangulasi sumber. Teknik analisis data yang digunakan Model Intraktif (Miles \& Huberman. 1992:19) meliputi pengumpulan data, reduksi data, penyajian data, dan penarikan kesimpulan atau verifikasi. Adapun proses analisis data dapat dijelaskan dengan Pengumpulan Data dilakukan dengan (wawancara, observasi, dan dokumentasi). Reduksi Data dilakukan pada nilai-nilai dalam prosesi merariq, pergeseran nilai dan implikasi adat 
merariq terhadap kehidupan keluarga, sosial dan hukum formal yang berlaku saat ini. Penyajian Data (data yang disajikan berupa data deskriftif mengenai fokus penelitian, foto-foto, hasil rekaman berupa hasil observasi dan wawancara mengenai prosesi dan implikasi merariq. Kesimpulan/Verivikasi dilakukan dengan pengujian kebenaran yang disesuaikan dengan validitasnya dengan teknik triangulasi data.

\section{HASIL DAN PEMBAHASAN}

Merariq adalah sebuah adat dalam perkawian yang dimiliki oleh masyarakat Sasak dan sudah menjadi identitas mereka. Adapun alasan masyarakat Lendang Nangka merariq adalah suatu bentuk tindakan yang tergolong dalam tindakan sosial. Suatu tindakan dianggap sebagai tindakan sosial apabila tindakan tersebut mempengaruhi atau dipengaruhi oleh orang lain. Tindakan sosial itu sendiri adalah tindakan manusia yang dapat mempengaruhi individu-individu lainnya dalam masyarakat. Tindakan sosial dibedakan ke dalam empat jenis tindakan yaitu Rasionalitas Instrumental, Rasionalitas Nilai, Tindakan Afektif dan Tindakan Tradisional (Dhohiri, Taufiq Rahman 2003: 51-53).

Adapun dalam menganalisis ketiga alasan yang melatarbelakangi keenam pasangan itu untuk melakukan perkawinan dengan cara merariq digunakan jenis tindakan sosial rasionalitas instrumental dan tindakan tradisional.

Untuk melakukan merariq perlu pemikiran yang matang antara kedua belah pihak yaitu laki-laki dan perempuan, bagaimana langkah-langkah yang mereka ambil agar orang tua tidak merasa curiga dengan rencana pelarian mereka, dan harus adaya kesepakatan sehingga bisa terwujud prosesi merariq walaupun ada beberapa pasangan yang mana keputusan merariq hanya diambil oleh pihak laki-laki saja. Dalam hal ini merariq dijadikan sebagai alat untuk mencapai tujuan tertentu misalnya saja merariq yang dilakukan karena alasan orang tua tidak merestui hubungan yang mereka bina baik itu karena perbedaan status yang mereka miliki, karena adanya suatu paksaan dari orang tua untuk menikah dengan orang lain yang tidak dicintainya.
Adat merariq juga bisa dikategorikan pada tindakan rasional yang tradisional karena merariq adalah suatu kebiasaan yang sudah turun temurun dilakukan oleh masyarakat Sasak khususnya Lendang Nangka dan dijadikan sebagai budaya bersama. Adat merariq yang dilakukan oleh masyarakat Lendang Nangka umumnya merupakan suatu tradisi yang sudah ada karena dengan dia membawa lari perempuan dari pengawasan orang tuanya berarti menandakan bahwa mereka berdua telah mampu memegang tanggung jawab untuk mandiri menjalankan kehidupan bersama. Makna lain adalah "orang tua laki-laki berarti berari sudang berang" maksudnya siap mengambil resiko atas perbuatan anak laki-lainya. Dan dilakukan dengan pertimbangan yang matang baik dari kedua belah pihak maupun dari pihak laki-laki yan ingin melarikan perempuan yang dia cintai. Bahwa ini dapat dikategorikan kedalam tindakan tradisional karena mereka melakukan merariq karena memang sudah menjadi adat dan tradisi yang sudah turun temurun ada di desa Lendang Nangka. Dimana bila anak perempuan mereka diminta dengan terus terang, orang tua perempuan akan tersinggung karena anak perempuanya disamakan dengan benda atau barang lainnya. Dan disini dapat dilihat bahwa adat merariq yang dilakukan oleh beberapa pasangan tersebut ada yang tanpa sepengetahuan maupun ada yang memang diketahui oleh orang tuanya akan tetapi hal itu dibiarkan saja, atau malah ada orang tua yang menjadi dalang pelarian yang dilakukan oleha anaknya. Dan ada rasa kebanggaan tersendiri bagi orang tua yang anaknya dibawa lari oleh seorang pemuda,

Merariq dengan pelarian diri terkesan menjadi bentuk pilihan dalam sikap yang menggunakan legalitas adat sebagai instrumen pencapaian keinginan. Karena pilihan yang lain seperti perkawinan dengan meminang atau belako' terkadang cukup memberatkan dan membutuhkan modal dan kesiapan psikologis yang harus ditanggung oleh calon mempelai laki-laki. Kemungkinan lamaran ditolak dan tidak disetujui oleh wali perempuan karena perbedaan status sosial, syarat-syarat persetujuan dan lainnya yang harus dipenuhi oleh pelamar tidak kalah sering terasa memberatkan pihak laki-laki, maka lari 
bersama menjadi pilihan tepat bagi satu pasangan. melalui beberapa rangkaian prosesi tersebut mengandung nilainilai sebagai berikut:

\section{Nilai-nilai budaya}

Menurut pengamatan peneliti tentang nilai-nilai budaya yang hidup dan berkembang dalam adat perkawinan "merariq" pada masyarakat Suku Sasak khsusnya di Desa Lendang Nangka, diantaranya:

Nilai budaya yang menyangkut kepedulian terhadap lingkungan. Secara umum kepedulian lembaga adat dalam kaitannya dengan kepedulian terhadap lingkungan hidup ini dapat dibagi menjadi dua, yaitu kepedulian terhadap lingkungan hidup dalam arti fisik dan kepedulian terhadap lingkungan hidup dalam arti sosial. Masyarakat Lendang Nangka sangat peduli terhadap lingkungan sosialnya, seperti dalam menghadapi warga yang sedang menghadapi musibah atau sedang menghadapi acara-acara tertentu, misalnya pesta perkawinan, sunatan, aqiqah dan kematian. Hampir semua masyarakat ikut berpartisipasi baik dengan tanaga, barang atau uang. Dalam pemberian bantuan, tidak melihat status warga yang bersangkutan, semua warga memiliki hak dan kewajiban yang sama. Sikap gotong royong, saling membantu, kerja sama dan hidup rukun sangat ditunjukkan masyarkatkan dalam pelaksanaan upacara adat merariq di desa Lendang Nangka

Nilai budaya yang menyangkut keadilan, tercermin dari tata cara dan pelaksanaan hukuman dari penentuan sanksi sampai penentuan hukuman dalam adat kawin lari "merariq" yang merupakan perkawinan adat masyarakat Suku Sasak. Penegakan hukum dan sanksi adat secara tegas dan adanya perasaan malu masyarakat terhadap perbuatan yang menyimpang ini sangat besar pengaruhnya dalam mengatur kehidupan sosial masyarakat di Desa Lendang Nangka. Setiap pelanggaran adat langsung ditindak dan pelaksanaan hukumannya disaksikan oleh masyarakat banyak. Hal ini menyebabkan warga masyarakat berfikir panjang untuk melakukan pelanggaran adat. Karena meskipun dia sendiri yang melakukan pelanggaran adat, yang kena getahnya bukan hanya dia sendiri, tapi semua keluarganya. Hal ini yang mendorong anggota masyarakat senantiasa bertindak dan berperilaku sesuai ketentuan adat. Karena itu tidaklah mengherankan bila di Desa Lendang Nangka kerukunan antar warga terjalin dengan baik bahkan dengan warga di desa-desa sekitarnya.

Nilai budaya menyangkut kesetiaan. Kesetiaan ini ditunjukkan masyarakatnya bukan hanya pada bentuk adat perkawinannya saja. Melainkan menyangkut beberapa masalah kehidupan seperti kesetian pada pemimpinnya dalam hal ini orang yang dituakan di Desa Lendang Nangka. Bentuk kesetiaan masyarakat terhadap pemimpinnya dapat dilihat dari ketaatan masyarakat dalam menjalankan aturan-aturan (awig-awig) dan keputusan-keputusan yang dibuat oleh pemimpin. Dan ada perasaan malu masyarakat terhadap perbuatan-perbuatan yang menyimpang. Kepatuhan atau kesetiaan masyarakat terhadap pemimpin desa atau terhadap pemimpin adat (tau lokak empat) di Desa Lendang Nangka masih sangat kentara, misalnya ketaatannya dalam menjalankan gotong royong, kepatuhan-kepatuhannya dalam menjalankan keputusan pemimpin. Perasaan malu terhadap perbuatanperbuatan yang menyimpang juga masih nampak. Bila ada anggota masyarakat yang melakukan perbuatan menyimpang dan diketahui oleh masyarakat, maka dengan sendirinya masyarakat tersebut akan ke luar dari desa atau membayar denda sebagai sanksi adat.

\section{Nilai-nilai pendidikan}

Nilai pendidikan ini ditanamkan pertama kali dari keluarga, masyarakat dan pemerintah. Melalui pendidikan manusia memiliki kemampuan dan wawasan yang luas dalam hidup bermasyarakat. Adat kawin lari "merariq" yang dimiliki masyarakat Suku Sasak masih dapat bertahan sampai saat ini karena di dalam serangkaian prosesi adat tersebut terdapat nilai-nilai pendidikan. Menurut analisa peneliti nilai-nilai pendidikan yang terdapat dalam adat merariq ini mengajarkan nilai tanggung jawab seorang lak-laki. Tanggunh jawab yang dimaksud yaitu Sikap dan perilaku seseorg untuk melaksakakan tugas dan kewajibannya, yang seharusnya dia lakukan terhadap diri sendiri, masyarakat, lingkungan (alam, sosial dan budaya ), Negara dan Tuhan Yang Maha Esa. 
Adat kawin lari "merariq" ini juga mengandung nilai pendidikan hukum adat yang digunakan dalam menyelesaikan serangkaian prosesi adat dalam pelaksanaannya. Melalui hukum adat inilah pelaksanaan adat merariq diatur sedemikian rupa tanpa mengabaikan hukum agama dan hukum formal (Undang-undang Perkawinan) yang berlaku di Indonesia. Nilai filosofi merariq yang menggambarkan sikap kesatria seorang lakilaki karena melarikan calon istrinya juga dapat dimasukkan ke dalam nilai pendidikannya. Terakhir adalah nilai sosiologi dalam adat merariq ini. Secara umum semua prosesinya mengandung nilai ini, karena terjadi interaksi adanya kontak dan komunikasi antara orangorang yang terlibat didalamnya.

\section{Nilai-nilai agama atau religius}

Sikap dan perilaku yang patuh dalam melaksanakan ajaran agama yang dianutnya, toleran terhadap pelaksanaan ibadah agama lain, dan hidup rukun dengan pemenuk agama lain juga dapat dilihat pada kehidupan masyarakat di desa Lendang Nangka. Perkawinan adat merariq pada masyarakat Suku Sasak pada prinsipnya masih berpegang teguh pada nilai-nilai agama atau geligius berdasarkan ajaran Islam sebagai agama yang banyak dianut masyarakatnya. Dalam pelaksanaan prosesi adat merariq nilai-nilai agama ini dapat dilihat pada saat midang, pasebo'an (sebo) atau tempat persembunyian dan bait wali.

\section{Nilai-nilai ekonomi}

Secara umum nilai ekonomi identik dengan nilai tukar atau materi. Nilai ini juga berlaku pada semua sistem perkawinan yang ada di Indonesia tak terkecuali di Desa Lendang Nangka sebagai lokasi penelitian. Adat kawin lari "merariq".

\section{Nilai Seni}

Perkawinan adat kawin lari "merariq" yang dilakukan masyarakat Suku Sasak mengandung unsur dan nilai seni. Hal ini terlihat pada prosesi nyongkolan yang menggunakan beberapa kesenian daerah yang dimiliki masyarakatnya seperti gendang beleq, cilokak atau kecimol. Penggunaan kesenian tersebut bertujuan untuk mengundang perhatian masyarakat akan iring-iringan pengantin atau lebih dikenal dengan istilah nyongkolan.
Kesenian yang sering digunakan dalam acara ini yaitu seni musik.

Dalam perkembangannya adat merariq pada masyarakat Suku Sasak khususnya di Desa Lendang Nangka mengalami pergeseran. Atau oleh para ahli hukum dinamakan erosi hukum adat. Erosi ini berupa melemahnya kekuatan berlakunya hukum adat dalam masyarakat adat.

Berdasarkan hasil penelitian dilapangan diketahui bahwa di wilayah Lendang Nangka pelaksanaan adatnya masih sangat kental termasuk dalam upacara-upacara atau prosesi-prosesi adat kawin lari "merraiq" yang menjadi identitas masyarakat Suku Sasak. Adapun perubahanperubahan bentuk dan nilai perkawinan dalam masyarakat Suku Sasak di desa Lendang Nangka meliputi : perubahan lambat dan perubahan yang direncanakan. Perubahan lambat terjadi dengan cara semakin berkurangnya anggota masyarakat yang peduli dan mempertahankan tradisi budaya mereka. Jika pada generasi dulu, dapat dikatakan bahwa keseluruhan masyarakat sangat kuat memegang aturan budaya terutama dalam prosesi perkawinannya sekarang yang terjadi pada generasi mudanya adalah sebaliknya. Mereka seolah-olah cuek bahkan tidak mengenal lebih dalam mengenai budaya adat perkwinannya sendiri. Sedangkan perubahan yang direncanakan terjadi dalam prosesi budaya perkawinan pada masyarakat Desa Lendang Nangka tanpa disadari dan tidak direncanakan. Hal ini terlihat pada sistem perkawinannya yang tidak hanya menggunakan cara kawin lari "merariq" saja.

$$
\text { Sedangkan jenis-jenis perkawinan yang }
$$
mengalami perubahan diantaranya: midang dan proses merariq. Dalam hal pergeseran bentuk pelaksanaan midang, terjadi perubahan yang sangat besar. Menurut pengamatan peneliti, perubahan dengan terjadinya pelanggaran konsep pada tataran budaya ini terjadi pada segenap masyarakat di desa Lendang Nangka, seperti: a) Midang dapat saja dilakukan kapan saja dan tidak lagi harus dilakukan pada malam hari, b) Nampak terjadi kebebasan dalam mengadakan pertemuan antara sepasang kekasih. Mereka dapat bertemu dimana saja dan tidak lagi harus di rumah sendiri. 
Sedangkan dalam proses merariq saat ini masyarakat sering tidak lagi menggunakan prosesi adat merariq secara lengkap dan utuh. Banyak serangkain prosesi yang mulai ditiadakan dengan alasan menghemat waktu, tenaga dan biaya.

Implikasi merariq atau kawin terhadap hukum formal saat ini. Kita mengetahui bahwa hukum adat berlaku sepanjang tidak bertentangan dengan kepentingan nasional. Hukum adat di dalam kehidupan sehari-hari selalu mengikuti gerak perubahan masyarakat. Oleh karenanya hukum adat harus dipakai sebagai landasan atau pedoman bagi Hakim yang diancarn hukuman penjara ole KUH Pidana.

Uraian tersebut di atas dapat memberikan ilustrasi atau gambaran bahwa masalah perbuatan melarikan orang perempuan dengan maksud untuk perkawinan yang banyak terjadi di kalangan muda mudi Masyarakat Suku Sasak di masa sekarang berlanjut sampai ke meja hijau. Tentunya hal ini berdasarkan pengalamanpengalaman yang terjadi.

Dapat dipahami bahwa apabila terjadi perbuatan melarikan orang perempuan pada Masyarakat Suku Sasak adalah sebagian besar disebabkan adanya faktor hubungan pergaulan sebelumnya di antara kedua belah pihak. Di kalangan muda mudi merupakan buah cinta atau puncak dari cinta kasih. Apabila perbuatan itu merupakan tindakan sepihak atau kedua pihak bersama, apakah hal itu diketahui pihak orang tua atau wali ataupun tidak, bagi muda mudi Masyarakat Suku Sasak bukan persoalan, bagi mereka buah cinta bila mungkin akan diranumkan dan diwujudkan dalam wadah perkawinan.

Pada Masyarakat Suku Sasak mengenai izin orang tua atau walinya tentu dapat dipahami bahwa tidak akan ada izin orang tua terhadap perbuatan anak atas kemauannya sendiri, begitu pula bukanlah kawin lari atau kawin melarikan namanya apabila ada izin orang tua atau wali yang sifatnya sempurna. Bagi Masyarakat Suku Sasak yang menganut adat kawin lari sering terjadi kepergian si anak wanita untuk bersuami diketahui ibunya, atau sekurang-kurangnya diketahui oleh bibik atau adiknya.

Apabila perkawinan itu menjadi gagal, si anak perempuan diambil pihak orang tuanya kembali dari tangan pihak orang tua si lelaki dikarenakan uang jujur yang tidak bisa dipenuhi pihak lelaki merasa terhina (dirugikan) kehormatannya oleh pihak si perempuan dalam acara perundingan lamaran. Maka pihak alat negara tidak boleh menerima pengaduan dan penuntutan karena bertentangan dengan hukum adat yang berlaku dan perbuatan tersebut tercela dalam Masayarakat Suku Sasak.

Dari uraian tersebut di atas dapat dikonklusikan bahwa dalam rangka pembinaan hukum nasional pasal 332 KUH Pidana sudah tidak sesuai lagi dengan perkembangan Masyarakat Suku Sasak dan memang tidak sesuai dengan Hukum Adat. Oleh karena itu perbuatan melarikan orang perempuan untuk maksud perkawinan bukan tindak pidana, apabila perbuatan melarikan itu merupakan perkawinan lari bersama atau perkawinan melarikan, baik ha1 itu dilakukan oleh mereka yang menganut adat perkawinan lari atau tidak. Sebagai bahan pertimbangan bagi peradilan dalam memposisikan perbuatan melarikian orang perempuan dengan maksud melakukan perkawinan itu bukan suatu tindak pidana tetapi itu adalah termasuk dalam ruang lingkup atau kajian Hukum Adat yang dimiliki oleh masyarakat Suku Sasak.

\section{SIMPULAN DAN SARAN}

Pertama, Nilai-nilai yang terkandung dalam prosesi adat "merariq" ini antara lain nilai-nilai budaya, nilai-nilai pendidikan, nilai agama, nilai ekonomi dan nilai seni. nilai-nilai budaya ini menyangkut kepedulian terhadap lingkungan hal ini dapat dilihat pada masyarakat Desa Lendang Nangka yang memiliki sikap gotong royong, saling membantu, kerja sama dan hidup rukun sangat ditunjukkan masyarakat dalam pelaksanaan upacara adat merariq. Nilai budaya menyangkut keadilan, tercermin dari tata cara pelaksanaan hukuman dalam adat "merariq" yang merupakan perkawinan adat masyarakat Suku Sasak dan nilai budaya menyangkut kesetiaan. Nilai-nilai pendidikan dalam adat merariq mengajarkan nilai tanggung jawab seorang laki-laki. Selain adat merariq juga mengandung nilai pendidikan hukum adat, hukum agama dan hukum formal (UU Perkawinan). Nilai-nilai agama dan religius dalam adat merariq dapat dilihat pada saat midang, pasebo'an (sebo) dan bait wali. Nilai-nilai ekonomi terlihat dalam pelaksanaan serangkaian prosesinya. Nilai 
seni dalam adat merariq dapat dilihat pada acara nyongkolan yang digunakan. Kedua, pergeseran nilai pada adat "merariq" pada masyarakat Suku Sasak dapat terlihat pada perubahan-perubahan bentuk dan nilai perkawinan meliputi proses midang dan proses merariq. Dalam proses merariq saat ini masyarakat sering tidak lagi menggunakan prosesi adat merariq secara lengkap dan utuh. Banyak serangkain prosesi yang mulai ditiadakan dengan alasan menghemat waktu, tenaga dan biaya.Ketiga, Implikasi Merariq terhadap pranata keluarga, sosial dan hukum formal saat ini. Kebiasaan yang terjadi pada Masyarakat Suku Sasak seorang wanita yang mempunyai status sosial bangsawan kawin dengan laki-laki bukan bangsawan dibuang keluarganya dan tidak diakui sebagai keluarga bahkan pihak perempuan tidak mendapat warisan dari orang tuanya. Akibatnya timbul reaksi dari kasta atau golongan jajar karang untuk tidak kawin dengan wanitawanita bangsawan karena akan mendapat kesulitan dalam hubungan kekerabatan di kemudian hari. Perkawinan yang tidak mendapat persetujuan dari orang tua sering berlanjut ke meja hijau karena dianggap merupakan tindakan penculikan yang melanggar hukum.

\section{DAFTAR RUJUKAN}

Bartholemew. 2001. Alif Lam Mim: Kearifan Masyarakat Sasak. Yogyakarta: Tiara Wacana

Daliem, M. Mimbarman. 2002. Lombok Selatan dan Pelaku Adat Istiadat Sasak, Proyek Penelitian dan Penerbitan Buku Majalah Pengetahuan Umum dan Profesi, Departemen Pendidikan dan Kebudayaan.

Lukman, H. Lalu. 2008. Tata Budaya Adat Sasak Lombok.

Moleong, Lexy.2007. Metode Penelitian kualitatif. Bandung: Rosda Karya.

Rato, Dominikus. 2011. HukumAdat (Suatu Pengantar Singkat Memahami Hukum Adat di Indonesia). Yogyakarta: LaksBangPRESSindo.

Salam, Solichin. 1992. Lombok Pulau Perawan : Sejarah dan Masa Depannya. Jakarta : Kuning Mas

Sugiyono. 2008. Metode Penelitian Kuantitatif, Kualitatif dan $R \& D$. Bandung: Alfabeta.

Zuhdi, M. Hafid. 2004. Parokilaitas Adat Islam Wetu Telu dalam Prosedur Perkawinan di Bayan Lombok. Tesis Program Pascasarjana UIN Jakarta. 